\title{
Psychoanalysing the 21st Century: Introduction
}

\author{
Mark Featherstone ${ }^{1}$
}

Published online: 9 May 2020

(c) Springer Nature B.V. 2020

\begin{abstract}
The purpose of this introduction is to sketch out the value of psychoanalysis for the twenty-first century and in particular the ways in which analysis might enable us to move beyond the crisis of the post-Cold War symbolic order.
\end{abstract}

Keywords Psychoanalysis $\cdot$ History $\cdot$ Symbolic system $\cdot$ Crisis $\cdot$ Mourning $\cdot$ The future

The objective of this collection of articles is to explore the purpose, relevance, and potentially some of the key socio-political problems which psychoanalysis might address in the early twenty-first century. As I write in the middle of lockdown imposed to slow the spread of the coronavirus many of the social, psychological, and behavioural certainties that had anchored the self in recent history have been thrown into doubt. What was predictable is now entirely uncertain. The normal socio-symbolic order, made up of the signs, symbols, ways of thinking, and everyday behaviours which once organised life, now seems like a fading memory that we struggle to remember in order to ensure that we live something like predictable lives. Although the virus has exploded the psycho-social laws of normality in the most dramatic fashion, leading to the need to establish some kind of liveable new normal, it is important to remember that psychoanalysis teaches us that the law is never fixed, but rather a symbolic construct that changes depending on the prevailing social conditions. In the late nineteenth century and early part of the twentieth century Freud wrote of the Oedipus complex, the incest taboo, and the law of the father, explaining that all forms of authority issue from this (oedipal) law of individualisation, separation, and rejection of the embrace of the mother. According to Freud there is no salvation in maternity. In fact, it is much worse than that because it turns out that the womb is a tomb.

While this psychoanalytic theory of the law held up until the middle of the twentieth century and faithful supporters, such as Jacques Lacan, continued to defend the

Mark Featherstone

m.a.featherstone@keele.ac.uk

1 Sociology, Keele University, Keele, Staffordshire ST55BG, UK 
law of Oedipus up to the end of the century, by the late 1960s the idea that repression should be thought about in terms of being the necessary basis of social order came under increasing attack from those who thought that the law of the father was never about turning people into social animals, but rather keeping the patriarch in power. In this view Oedipus was always an underhand strategy meant to convince people that repression was necessary and to keep old men in positions of authority. The key theorists of this critique, including Deleuze and Guattari, Foucault, Marcuse, and Laing, championed the psychology of the (post-capitalist) individual, difference, and the imagination and sought to establish a new law based upon creativity, desire, and self-making outside of the repressive structure set up by the Freudian model. This was a new utopia of freedom that contrasted sharply with Freud's dystopia of repression and social control. Despite the fact that it is still easy to read many of these post-Freudian writers for their utopianism today, the problem is that their approach was quickly subsumed into what Boltanski and Chiapello [1] have called the new spirit of capitalism. As Boltanski and Chiapello show in their book on this new economic spirit, creativity, imagination, and desire were now the necessary attributes for success in the new system of production and consumption that established itself in the late 1970s through the 1980s up to the 1990s when this new version of capitalism became the global norm.

In the late 1980s through to the late 1990s the fall of Berlin Wall, collapse of the Soviet Union, and the rise of the internet signalled the passing of the Freudian authoritarian model and the complete domination of the new psycho-social law founded upon creativity and innovation. This was the new law of self-realisation, individualism, and becoming. The father was no more. His children had taken over. The self was now no longer made by social regulation, but rather took the form of an increasingly fluid construct endlessly in the process of being made and re-made in social situations that were similarly shifting and relentless in their transformations. However, it was precisely at this point, the point when the American political theorist Frances Fukuyama [2] proclaimed the absolute domination of the new law in his famous statement about the end of history, that the Hegelian cunning of reason started to kick in and the new socio-symbolic legal system began to unravel. Signs of the new law's collapse came thick and fast in the early years of the twenty-first century. The terror attack on the World Trade Centre in New York first signalled the vulnerability of American power, but worse was to follow. 9/11 was quickly followed by the abortive wars in Afghanistan and Iraq that destabilised the Middle East leading to the rise of Islamic State and the ongoing catastrophe in Syria. By 2008 the global financial system was in meltdown and the fantasy of capital unleashed and endless prosperity born in the collapse of Soviet Union was shown to be little more than an accounting trick. At the same time that the global financial system went into a tailspin brought about by the transformation of the virtual, weightlessness of easy credit into the unbearable weight of debt, the ecological limits of capitalist civilization that had been known since the early 1970s became completely clear in mounting evidence of global warming that continues to threaten mass extinction. At this point it started to look as though we were, as Zizek [5] put it, living in the end times.

Of course, there has been plenty of resistance to this situation and many refused to accept the end of business as usual. Nobody wants to face up to the end times, but 
some thought they could escape the consequences of the end of capitalist normality by taking flight into the past. In the face of the collapse of the post-Cold War state of normality Americans elected Donald Trump to the office of President in order to right the ship and make America great again. The British were similarly looking to their own past of imperial power when they voted Brexit and elected a Prime Minister (Boris Johnson) who models himself on Churchill. The objective here was to 'take back control' and escape the misery of the present into some long forgotten golden age that probably never existed in the first place. Alongside other populist strong men, Bolsonaro, Orban, Erdogan, and, of course, Putin, the election of these figures sparked a culture war about what might happen next, between those on the side of the law of the individual and self-realisation and those who wanted to track further back to Freud's patriarch who insisted upon the law of old men and a return to traditional social structure based upon gender normalisation and so on. But it is perhaps the final shock of the coronavirus pandemic, which telescopes the scales of the microscopic virus that seems to be endlessly transmissible and the macroscopic global system on the verge of collapse, that surely signals that the post-Cold War normal is over and that we are also probably beyond a choice between the postmodern and pre-modern versions of normality and must instead invent an entirely new way of living. How can we, however, imagine this new law? What would it look like?

In the context of this critical situation perhaps the key challenges of psychoanalysis in the early twenty-first century will become about working through past modes of normality, coming to terms with their passing and learning to move on, and finally seeking out some new form of law to structure behaviour and make sense of the world. Given these challenges, the following articles are concerned with making sense of crumbling normality, taking stock of a situation that seems to represent the end of the latest version of socio-symbolic law, and searching for new ways forward into the future without very much sense of what might come next. To this end, the collection begins with my own exploration of the shift from what I call the Freudian 'normalisation project', through the Deleuzean 'individualisation project', up to an exploration of the impact of Lacan's revised (computational) Freudianism, which we might think about through the lens of Shoshana Zuboff's [6] recent work on surveillance capitalism. In order to respond to the realisation of this behavioural dystopia, where the human is little more than a cybernetic switching machine caught between being and non-being, I turn to consideration of Bernard Stiegler's [4] work and sketch out his neganthropic 'survival project' focused on saving the human from the post-human nihilism of the late capitalist anthropocene.

Following this contribution, psychoanalyst Dany Nobus takes up the contemporary problem of manliness in his piece 'Arresting Masculinity', explaining that it is possible to see toxic masculinity as a kind of pharmakon that simultaneously poisons and cures the fragmented socio-symbolic system. Against the backdrop of a toxic culture of anger brought about by the failure of reason in a global capitalist society that seems to have completely lost its bearings, Nobus argues that 'man' has become a sign of everything that is wrong with the world. He has become a Girardian [3] scapegoat, a figure that paradoxically explains the broken social system and somehow holds it together on the basis that everybody else can agree that this 
bad mannered, '...self-absorbed, authoritarian, reactionary, disrespectful, bigoted, misogynistic, sex starved, loud-mouthed, sleazy, ignorant, lazy, arrogant...' figure has no place in the world. The irony of this set-up is, of course, that it is precisely the vilification of this 'unreconstructed man' that makes him absolutely necessary, prevents the social system from ever moving beyond him, and thus ensures that Trump and the other strong men have no reason to worry about their future. They will remain popular precisely because of their toxic nature, which, Nobus points out, is defined by signifiers relating to a particular take on the idea of 'masculinity', rather than men themselves who may equally find themselves suffering under the rule of the perverse patriarch.

Building upon Nobus' exploration of toxic masculinity, political theorist Moran Mandelbaum explains the political psychology of Brexit, and shows how the 'Leave' campaign relied on a utopian fantasy of the past, a kind of retrotopia, to capture the desire of people who felt that they had no future in neoliberal globalisation. In this respect the hope of Brexit was that Britain could escape from a failing present into a future past where it would take back control and stand on its own two feet. However, in much the same way that Nobus shows how the utopia of the cultural left relies on the figure of perverse father which it can never overcome or leave behind, Mandelbaum's point is that the Brexiteers' fantasy of a return of pax Britannica was and remains absolutely reliant on the existence of the other (the foreigner, the liberal, the feminist and so on) who simultaneously prevents the realisation of the conservative utopian idea and ultimately ensure it remains a viable object of desire endlessly on the horizon. In this respect Mandelbaum shows how the idea of escape through Brexit is a fatal strategy, regardless of whatever happens in the future, simply because the Brexiteers' nationalist project is turned towards an imagined past that can never be recovered and the existence of a demonic other who will never disappear (or go home), simply because they are the fantastical, constitutive figure of the nationalist imagination.

While Nobus and Mandelbaum interrogate the psycho-politics of the cultural left and nationalist right and essentially show why both are fatally bound up with the fantasy of the other (the primal father in the case of the left; the post-modern other in the case of the right) which means that they can never escape the past into the future, James Hardie-Bick explores the potential violence lurking in forms of politics that rely on the exclusion of some other in a name of the formation of the law through a detailed reading of C. P. Taylor's play Good. The key point of Hardie-Bick's reading, which involves an exploration of Fromm, Arendt, Bauman, and Becker on the psychology of evil, is that the problem of symbolic systems that rely on othering in order to constitute some sense of a law is that they can very easily lead to the normalisation of the most horrendous forms of violence. While the focus of Hardie-Bick's piece is the legitimation of violence and the construction of the other in Nazi Germany, he is alive to the possibility of mass violence in the future and presents Good as a cautionary tale of the dangers of slipping into a situation where the destruction of the other becomes the price that must be paid for the formation of a new socio-symbolic system. Now in a sense this is precisely what Bruce Arrigo and Brian Sellers explore in their piece that follows Hardie-Bick's contribution to the collection with the difference that in their vision of a new legal regime 
everybody is the potentially criminal other in a vast process organised around the elimination of crime, deviance, or, thought about from an alternate perspective, the freedom to make the future.

While Hardie-Bick remains focused on the historical case of Nazism, Arrigo and Sellers consider the possibility of the emergence of a new kind of futuristic totalitarianism, which is similar to what Zuboff [6] calls instrumentarianism, developed under conditions of digitisation. In explaining the development of what they term the sign-optic system of governmentality through reference to Foucault, Mathiesen, and Bigo, Arrigo and Sellers capture the problem of what happens when socio-symbolic order tips over into the emergence of a hyper-control system, capable of transforming individuals into data doubles or an algorithmic form of humanity, which promises to prevent crime from ever taking place. In this sense Arrigo and Sellers set out the possibility of a new high tech approach to policing based upon digital people-making psycho-technologies similar to those currently employed by Google and Facebook. While Google and Facebook want to ensure absolute predictability of consumer choice, thus making sure that advertisers can be certain their content connects with users, the objective of pre-crime policing is the detection of deviance before it ever happens and the creation of a post-criminological society that closes the loop of law and the compliance of the new dividual. Beyond this dystopian vision of computational law and the abolition of crime which, in this case, includes the freedom to think beyond algorithmic governmentality, in the final article in the collection psychoanalyst Stephen Frosh writes about the phenomenon of postmemory and the possibility of overcoming the repetition of violence brought about by the inability to move beyond past trauma.

Starting with the idea of hyperconnection, Frosh explains that in the early twentyfirst century age of new media we have come to think about excessive connectivity in terms of horizontal connection across space that effectively abolishes time. However, he points out that what this view ignores is the phenomenon of vertical hyperconnection through time that involves the telescoping of past and present and the possession of the contemporary moment by the restless ghosts of those who were never properly laid to rest. According to Frosh this situation is the result of an inability to mourn, work through trauma, and come to terms with the past that ends up blocking the possibility of a future different from the past. Thus the effect of failed mourning and the denial of trauma is the frozen repetition of the past, haunting, and a kind of funereal present lived in the shadow of what has gone before. In illustrating this condition Frosh refers to the case of the Brazilian Truth Commission concerned to investigate the violent history of the dictatorship that lasted from the mid1960s to mid-1980s which found that many Brazilians had never come to terms with the impact of the fifth republic and felt nostalgic for the period, claiming that 'things were better in the old days'. In Frosh's view the effect of this failure to make peace with the ghosts of the past is that Brazil easily slipped back into extremism with the election of Jair Bolsonaro, leading to the overall conclusion that if we are ever to escape the repetition of historical mistakes and found new socio-symbolic laws that are more than simply high-tech versions of the past then we must undertake the painful analytic work of remembering, recognising what has already happened, and acknowledging the damage done. 
How, then, might we conclude our attempt to psychoanalyse the early twenty-first century? There is no easy answer to this question, simply because analysis itself takes time and hard work, but I would risk the claim that if psychoanalysis has one fundamental purpose in the early twenty-first century it is probably to enable us to come to terms with the end of post-Cold War symbolic order and to open up the possibility of a future that is not simply a ghostly repetition of the past haunted by those who have been left behind, but never properly mourned.

\section{References}

1. Boltanski, L., and E. Chiapello. 2006. The New Spirit of Capitalism. London: Verso.

2. Fukuyama, F. 1992. The End of History and the Last Man. New York: The Free Press.

3. Girard, R. 1989. The Scapegoat. Baltimore: Johns Hopkins University Press.

4. Stiegler, B. 2019. The Age of Disruption: Technology and Madness in Computational Capitalism. Cambridge: Polity Press.

5. Zizek, S. 2010. Living in the End Times. London: Verso.

6. Zuboff, S. 2019. The Age of Surveillance Capitalism: The Fight for a Human Future at the New Frontier of Power. London: Profile.

Publisher's Note Springer Nature remains neutral with regard to jurisdictional claims in published maps and institutional affiliations. 